Research Article

\title{
Aggression among School Adolescent and its Association with Socio-Demographic Characteristics: A Cross Sectional Study
}

\author{
Jugal Kishore', Nalini Tripathi' $^{2}$, Ranjit Kumar Mandal ${ }^{3}$, Satendra Kumar Tomar ${ }^{4}$ \\ ${ }^{1}$ Director Professor \& Head, Department of Community Medicine, VMMC \& Safdarjung Hospital, New Delhi. \\ ${ }^{2}$ Scientist-C, ICMR Project, VMMC \& Safdarjung Hospital, New Delhi. \\ ${ }^{3}$ Principal, BGS World School Chikballapur, Karnataka. \\ ${ }^{4}$ Director Administration, NH Goel World School, Raipur. \\ DOI: https://doi.org/10.24321/2349.2880.201908
}

I $\quad \mathbf{N} \quad \mathbf{F} \quad \mathbf{O}$

\author{
Corresponding Author: \\ Dr. Nalini Tripathi, ICMR Project, VMMC \& \\ Safdarjung Hospital, New Delhi. \\ E-mail Id: \\ neha.nalini@gmail.com \\ Orcid Id: \\ https://orcid.org/0000-0002-1159-8672 \\ How to cite this article: \\ Kishore J, Tripathi N, Mandal RK, Tomar SK. \\ Aggression among School Adolescent and \\ its Association with Socio-Demographic \\ Characteristics: A Cross Sectional Study. Ind J \\ Youth Adol Health 2019; 6(2): 7-13.
}

Date of Submission: 2019-10-22

Date of Acceptance: 2019-11-25

\section{$\begin{array}{llllllll}\mathbf{A} & \mathbf{B} & \mathbf{S} & \mathbf{T} & \mathbf{R} & \mathbf{A} & \mathbf{C} & \mathbf{T}\end{array}$}

Background: Increasing aggression and violent behaviors in adolescents present serious challenges for public health. Children with persistent high levels of aggressiveness are often associated with developing conduct disorders later in life.

Objectives: (1) To identify aggression among school adolescents. (2). To find out the association of aggression with different socio-demographic characteristics among these students.

Methods: It was a school based cross sectional study conducted in one of the private schools in Raipur, Chhattisgarh. Study population comprised of 319 adolescents studying in classes $9^{\text {th }}-12^{\text {th }}$. A pre-tested, semi-structured, self-administered questionnaire was distributed to the study subjects. For assessing aggression, a modified version of Direct and Indirect Aggression Scale (DIAS) was used. Data was analyzed by using frequency tables and significant association was established by chi-square test.

Result: A large proportion of adolescents scored high on each item of aggression scale. Males adolescents displayed significantly higher levels of aggressiveness as compared to female. Younger age showed higher level of aggressive scores than older age groups. Adolescents who were Hindus and had nuclear families with educated parents were found to have high aggressive scores as compared to other religion and joint families. However, these differences were not statistically significant.

Conclusions: There is high aggression level among school adolescents which needs effective preventive and management strategy.

Keywords: Adolescent, Aggression, School Going Children, DIAS 


\section{Introduction}

Aggression and violence among youth presents a serious challenge for public health which results inconsiderable suffering to individuals and heavy socio-economic burden to the society. ${ }^{1,2}$ It is also one of the most prevalent behavioral aspects in children which cause a lot of concern in present days. Aggression is generally defined as a behavioral act that results in hurting or harming others. It engulfs a wide spectrum of behaviors, which varies from covert to overt display of aggressive behaviors. Ferguson and Beaver defined aggressive behavior as "Behavior which is intended to increase the social dominance of the organism relative to the dominance position of other organisms". ${ }^{3}$ Bjorkvists (1992), identifies three different type of aggression using DirectIndirect Aggression Scale i.e. Direct, Indirect and Verbal Aggression. ${ }^{4}$ Children engaging in direct aggression usually display it in physical form, like hitting, kicking, punching, biting and so on. Indirect Aggression is shown by exclusions, social isolations, spreading rumors, telling other's secret and so on. Verbal aggression is displayed by using bad words, abuses, threatening others, calling names and so on. According to a study, nearly $18.6 \%$ of females aged $12-17$ got into a serious fight at school or work. $14.1 \%$ participated in a group-against-group fight and 5.7\% attacked another person with an intent to seriously harm him/her. ${ }^{5}$

Aggression is related to mental health problems in children which includes external disorders like Oppositional Defiant Disorder and Conduct Disorder and internal problems like Depression and Anxiety (American Psychiatric Association, 1994). It is therefore seen as a dysfunctional aspect of a Childs' development and growth. ${ }^{6}$

The increasing crime rates and violent activities of youth in India have made the researchers to study aggression among youth. Therefore, it becomes very crucial to identify the problem behaviors early in the school age and provide appropriate prevention mechanisms. There is a need for the proper assessment of youth for aggression and development of prevention and intervention modules for youth in Indian context. The present study aims to understand to identify aggression among school-going adolescents and to find out different socio-demographic characteristics associated with aggression among these students.

\section{Methods}

Study Design: It was a school based cross-sectional study.

\section{Study Area and Study Population}

The study was conducted in the rural area of Raipur, Chhattisgarh. It is a private school having classes from $1^{\text {st }}$ to $12^{\text {th }}$ standard. Students from rural as well as urban area are coming to attend the school. Study population comprised of children studying in classes $9^{\text {th }}-12^{\text {th }}$ standards.

\section{Study Duration}

This study was conducted for one month ( $1^{\text {st }}$ August- $1^{\text {st }}$ September 2017). A total of 319 students participated in the study. To recruit the students, permission was sought from the principal of the school. After obtaining the written consent form the principal questionnaire was distributed to the students in their classrooms during a pre-arranged time. Efforts were made to ensure that the students had privacy while completing the questionnaire.

\section{Sample Size}

Convenient sampling was done because of limitation of study duration and resources. The sample size was calculated using the formula, $\mathrm{N}=\mathrm{Z} \alpha 2 \mathrm{pq} / \mathrm{L} 2$ where $\mathrm{N}=$ sample size, $\mathrm{Z} \alpha=1.96$ is the value of the standard normal variant corresponding to level of significance (alpha) $5 \%, p=$ total prevalence of aggression (17.7\%) taken from a previous study [7], $q=(1-p)$, $\mathrm{L}=$ allowable error $(5 \%)$. Adding a $10 \%$ non-response rate, the minimum sample size was found to be 256 .

\section{Study Tool}

A pre-designed, pre-tested, semi-structured, selfadministered questionnaire was used for data collection. Data was collected regarding the socio-demographic variables like age, sex, religion, type of family, education and occupation of parents. Apart from this, a modified version of Direct and Indirect Aggression Scale (DIAS) was also used for data collection. The DIAS questionnaire was developed by Björkqvist et al. ${ }^{4}$

\section{Statistical Analysis}

After collection of data it was double entered in Microsoft Excel Sheet and validated. A clean database was generated and copied into SPSS sheet (version 16.0). Then the whole data was analyzed in SPSS (version 16.0) by using frequency tables and significant association was established by chisquare test taking $p$-value $<0.05$. Distribution of study population according to age, sex, religion, type of families, working status of mothers and monthly income were analyzed. The distribution of participants according to beliefs supporting aggression were also analyzed. Association of total aggression scores with different socio-demographic parameters was analyzed. Chi square test of significance was performed to find out the association.

\section{Ethical Issues}

Consent was obtained from the principals of the concerned school and assent was taken from the participants. Study participants were assured of the confidentiality and were free to decline from participation.

\section{Result}

A total of 319 students participated in the study. Table 1 shows that nearly $23.5 \%$ students felt big and tough when 
they pushed someone around. About $42.6 \%$ of students agreed that if they backed down from a fight then everyone would think that he/she was a coward. Nearly $44.2 \%$ of students were in favor of having two choices only in a critical situation, i.e., get punched or punch the other adolescent first. About $16.8 \%$ of students agreed that it was ok to hit someone if they were just crazy with anger. $21.6 \%$ of students understood that a guy who did not fight back when other kids pushed him around would lose respect. About $46.1 \%$ of the students were of the opinion that a person virtually shows the liking about his friend if he gets in fights with other guys about him.

Table I.Belief supporting aggression in study subjects

$(\mathrm{N}=319)$

\begin{tabular}{|c|c|c|c|c|c|}
\hline Statements & $\begin{array}{c}\text { Strongly Agree } \\
\mathbf{n}(\%)\end{array}$ & $\begin{array}{c}\text { Agree } \\
\mathbf{n}(\%)\end{array}$ & $\begin{array}{c}\text { Neither } \\
\mathbf{n}(\%)\end{array}$ & $\begin{array}{c}\text { Disagree } \\
\mathbf{n}(\%)\end{array}$ & $\begin{array}{c}\text { Strongly disagree } \\
\mathbf{n}(\%)\end{array}$ \\
\hline $\begin{array}{c}\text { It makes you feel big and tough when you } \\
\text { push someone around }\end{array}$ & $30(9.4)$ & $45(14.1)$ & $68(21.3)$ & $89(27.9)$ & $87(27.3)$ \\
\hline $\begin{array}{c}\text { If you back down from a fight, everyone } \\
\text { will think you are a coward. }\end{array}$ & $50(15.6)$ & $86(27.0)$ & $69(21.6)$ & $65(20.4)$ & $49(15.4)$ \\
\hline $\begin{array}{c}\text { Sometimes you have only two choices-get } \\
\text { punched or punch the other kid first. }\end{array}$ & $61(19.1)$ & $80(25.1)$ & $76(23.8)$ & $48(15.0)$ & $54(16.9)$ \\
\hline $\begin{array}{c}\text { It's ok to hit someone if you just go crazy } \\
\text { with anger. }\end{array}$ & $29(9.0)$ & $25(7.8)$ & $40(12.5)$ & $97(30.4)$ & $128(40.1)$ \\
\hline $\begin{array}{c}\text { A guy who doesn't fight back when other } \\
\text { kids push him around will lose respect. }\end{array}$ & $31(9.7)$ & $38(11.9)$ & $49(15.4)$ & $102(32.0)$ & $99(31.0)$ \\
\hline $\begin{array}{c}\text { A guy shows he really likes his friend if he } \\
\text { gets in fights with other guys about him. }\end{array}$ & $60(18.8)$ & $87(27.3)$ & $67(21.0)$ & $60(18.8)$ & $45(14.1)$ \\
\hline
\end{tabular}

Table 2.Modified Direct and In-direct Aggression scale (DIAS): Item-wise distribution of response of adolescents over the last 7 days

$(\mathrm{N}=319)$

\begin{tabular}{|c|c|c|c|}
\hline Statements & $\begin{array}{c}\mathbf{0} \text { day } \\
\mathbf{n}(\%)\end{array}$ & $\begin{array}{c}\mathbf{1 - 3} \text { days } \\
\mathbf{n}(\%)\end{array}$ & $\begin{array}{c}\mathbf{4} \text { days } \mathbf{\&} \text { above } \\
\mathbf{n}(\%)\end{array}$ \\
\hline I teased students to make them angry & $169(53)$ & $108(33.9)$ & $42(13.2)$ \\
\hline I got angry very easily with someone. & $98(30.7)$ & $132(41.4)$ & $89(27.9)$ \\
\hline I fought back when someone hit me first. & $167(52.4)$ & $100(31.3)$ & $52(16.3)$ \\
\hline I said things about other kids to make other students laugh. & $131(41.1)$ & $122(38.2)$ & $66(20.7)$ \\
\hline I encouraged other students to fight. & $244(76.5)$ & $53(16.6)$ & $22(06.9)$ \\
\hline I pushed or shoved other students. & $234(73.4)$ & $65(20.4)$ & $20(06.3)$ \\
\hline I was angry most of the day. & $169(53)$ & $113(35.4)$ & $37(11.6)$ \\
\hline Got into a physical fight because i was angry. & $238(74.6)$ & $58(18.2)$ & $23(07.2)$ \\
\hline I slapped or kicked someone. & $224(70.5)$ & $72(22.6)$ & $22(06.9)$ \\
\hline I called other students bad names. & $195(61.1)$ & $85(26.5 \%)$ & $39(12.2 \%)$ \\
\hline I threatened to hurt or to hit someone. & $234(73.4)$ & $59(18.5 \%)$ & $26(8.2 \%)$ \\
\hline
\end{tabular}

Table 3.Distribution of total Aggression scores in study population

$(\mathrm{N}=319)$

\begin{tabular}{|c|c|}
\hline Total Aggression score & No. (\%) \\
\hline 0 & $37(11.6)$ \\
\hline $1-11$ & $144(45.1)$ \\
\hline $12-30$ & $112(35.2)$ \\
\hline $31-40$ & $11(03.4)$ \\
\hline 41 and above & $15(04.7)$ \\
\hline
\end{tabular}


Table 2, shows the responses of adolescents on aggression scale for given options how many times the student did it during last 7 days. The analysis shows that about $47.1 \%$ of study subjects used to tease other students to make them angry of which $13.2 \%$ did it for more than four times in a week. Nearly two third of the study subjects $(69.3 \%)$ got angry easily with someone; of which $13.5 \%$ subjects did it for more than six times. About $47.6 \%$ adolescents fought back when hit first; of which $11.6 \%$ did it for more than six times. Among adolescents, $58.9 \%$ used to tell things about other kids to make other students laugh. Most of them (76.5\%) had not encouraged other students to fight and nearly (73.4\%) of them not pushed/shoved other students.
Nearly $53 \%$ of them stated that during last 7 days they were not angry. About $74.6 \%$ students did not get into a physical fight in anger. About $29.5 \%$ of subjects slapped or kicked someone out of which $6.9 \%$ did it for more than 6 times a week. Nearly $38.7 \%$ participants called other students by bad names. Most (26.7\%) of the students have threatened to hurt or to hit someone more than one times in last 7 days.

Table 3, shows the aggregate scores on aggression scale in the study population. $11.6 \%$ of adolescents scored zero and $45.1 \%$ scored in between $0-11$. 35.2\% scored between $12-30,03.4 \%$ between $31-40$ and only $04.7 \%$ scored above 41 and above. Table indicates that $43.3 \%$ of adolescents had more than 12 scores.

Table 4.Distribution of average and total aggression scores according to sociodemographic characteristics of adolescents

\begin{tabular}{|c|c|c|c|c|c|c|}
\hline \multirow{2}{*}{ Variables } & \multirow{2}{*}{ No. (\%) } & \multirow{2}{*}{ Mean \pm SD } & \multirow{2}{*}{$\begin{array}{l}\text { K.S value } \\
\text { Sig. value }\end{array}$} & \multicolumn{2}{|c|}{ Total Aggression score (\%) } & \multirow{2}{*}{$\begin{array}{c}\text { p-value } \\
\text { chi square }\end{array}$} \\
\hline & & & & $0-11(\%)$ & 12 \& above (\%) & \\
\hline \multicolumn{7}{|l|}{ Gender } \\
\hline Male & $178(55.8)$ & $14.15 \pm 12.49$ & \multirow{2}{*}{$\begin{array}{c}1.54 \\
0.017\end{array}$} & $89(49.2)$ & 89 (64.5) & \multirow{2}{*}{$\begin{array}{c}7.45 \\
0.004 \\
\end{array}$} \\
\hline Female & $141(44.2)$ & $10.77 \pm 10.51$ & & $92(50.8)$ & 49 (35.5) & \\
\hline \multicolumn{7}{|l|}{ Age (years) } \\
\hline $12-13$ & $11(3.4)$ & $14.27 \pm 13.41$ & \multirow{4}{*}{$\begin{array}{c}3.82 \\
0.281\end{array}$} & $8(4.4)$ & $3(2.2)$ & \multirow{4}{*}{$\begin{array}{c}7.13 \\
0.068\end{array}$} \\
\hline $14-15$ & $175(54.9)$ & $13.13 \pm 13.1$ & & $99(54.7)$ & $76(55.1)$ & \\
\hline $16-17$ & $126(39.5)$ & $12.2 \pm 9.73$ & & $67(37.0)$ & $59(42.8)$ & \\
\hline $18-19$ & $7(2.2)$ & $5.28 \pm 4.23$ & & $7(3.9)$ & 0 & \\
\hline \multicolumn{7}{|l|}{ Religion } \\
\hline Hindu & $267(83.7)$ & $12.66 \pm 11.48$ & \multirow{2}{*}{$\begin{array}{l}0.899 \\
0.395\end{array}$} & $149(82.3)$ & $118(85.5)$ & \multirow{2}{*}{$\begin{array}{l}5.01 \\
0.28 \\
\end{array}$} \\
\hline Others & $52(16.3)$ & $12.61 \pm 13.21$ & & $32(17.6)$ & $20(14.4)$ & \\
\hline \multicolumn{7}{|l|}{ Type of Family } \\
\hline Nuclear & $174(54.5)$ & $12.51 \pm 12.46$ & \multirow{2}{*}{$\begin{array}{l}0.582 \\
0.777\end{array}$} & $105(58.0)$ & $69(50.0)$ & \multirow{2}{*}{$\begin{array}{c}2.02 \\
0.095\end{array}$} \\
\hline Joint & $145(45.5)$ & $12.82 \pm 10.90$ & & $76(42.0)$ & $69(50.0)$ & \\
\hline \multicolumn{7}{|l|}{ Education Father } \\
\hline Professional degree & $90(28.2)$ & $10.92 \pm 10.36$ & \multirow{6}{*}{$\begin{array}{c}6.19 \\
0.287\end{array}$} & $55(30.4)$ & $35(25.4)$ & \multirow{6}{*}{$\begin{array}{l}5.15 \\
0.39\end{array}$} \\
\hline Post Graduate \& above & $81(25.4)$ & $14.59 \pm 13.45$ & & $44(24.3)$ & $37(26.8)$ & \\
\hline Up to Graduate & $92(28.8)$ & $12.86 \pm 11.13$ & & $47(26.0)$ & $45(32.6)$ & \\
\hline Higher school diploma & $25(7.8)$ & $11.44 \pm 9.65$ & & $15(8.3)$ & $10(7.2)$ & \\
\hline Up to High school $\left(10^{\text {th }}\right)$ & $14(4.4)$ & $18.42 \pm 17.77$ & & $7(3.9)$ & $7(5.1)$ & \\
\hline Illiterate & $17(5.3)$ & $8.52 \pm 7.55$ & & $13(7.2)$ & $4(2.9)$ & \\
\hline \multicolumn{7}{|l|}{ Education Mother } \\
\hline Professional degree & $59(18.5)$ & $12.06 \pm 10.74$ & \multirow{6}{*}{$\begin{array}{c}2.74 \\
0.739\end{array}$} & 35 (19.3) & $24(17.4)$ & \multirow{6}{*}{$\begin{array}{l}4.10 \\
0.53\end{array}$} \\
\hline Post Graduate \& Above & $87(27.3)$ & $13.29 \pm 13.06$ & & $46(25.4)$ & $41(29.7)$ & \\
\hline Up to Graduate & $96(30.1)$ & $13.56 \pm 12.12$ & & $52(28.7)$ & $44(31.9)$ & \\
\hline Higher school diploma & $42(13.2)$ & $12.92 \pm 12.12$ & & $23(12.7)$ & $19(13.8)$ & \\
\hline Up to High school $\left(10^{\text {th }}\right)$ & $17(5.3)$ & $9.17 \pm 8.07$ & & $12(6.6)$ & $5(3.6)$ & \\
\hline Illiterate & $18(5.6)$ & $9.33 \pm 7.88$ & & $13(7.2)$ & $5(3.6)$ & \\
\hline
\end{tabular}




\section{Mother working Status}

\begin{tabular}{|c|c|c|c|c|c|c|}
\hline Working & $122(38.2)$ & $11.99 \pm 10.97$ & & $71(39.2)$ & $51(37.0)$ & 0.17 \\
\cline { 1 - 2 } $\begin{array}{c}\text { Non-working/ } \\
\text { Housewives }\end{array}$ & $197(61.7)$ & $13.07 \pm 12.23$ & 0.873 & $110(60.8)$ & $87(63.0)$ & 0.38 \\
\hline
\end{tabular}

Table 4, shows the association of average and total aggression scores with various socio-demographic characteristics of adolescents. The analysis reveals that $55.8 \%$ were males and $44.2 \%$ were females in the study. Male participants were found to have scored significantly higher $(p=0.004)$ than their female counterpart. Total aggression score was higher among adolescents aged 14-15 (55.1\%) followed by 16-17 years (42.8\%) as compared to those aged 12-13 and 18-19 years $(p=0.068)$. However, if we compare the mean values then, it was consistently decreasing as the age advanced. Although, there was no significant association ( $p=0281)$.

Majority belonged to Hindus (83.7\%) and the aggression scores were also higher among them. There was no association between type of families and aggression scores. As far as the education status of parents was concerned, majority of students have their parents with qualification up to graduate and above. However, it is observed that adolescents of professional, postgraduate \& graduate mothers had higher aggression scores (17.4\%, 29.7\%, 31.9\%) than those who had lower educated mother, although it shows no significant association. It is also observed that students' aggression scores were almost same when the working status of their mothers. However, mean scores on aggression scale among students of working mothers were less $(11.9 \pm 10.9)$ as compared to non-working mothers (13.0 \pm 12.2$)$.

\section{Discussion}

The present study revealed that nearly $23.5 \%$ of students felt big and tough when they pushed someone around. About $42.6 \%$ of students agreed that if they backed down from a fight then everyone would think that he/she was a coward. Nearly, $44.2 \%$ of students were in favor of having two choices only in a critical situation, i.e. get punched or punch the other kid first. About $16.8 \%$ of students agreed that it was ok to hit someone if they were just crazy with anger. $21.6 \%$ of students understood that a guy who did not fight back when other kids pushed him around would lose respect. About $46.1 \%$ of the students were of the opinion that a person virtually shows the liking about his friend if he gets in fights with other guys about him/her. Thus, it was found that nearly one-third of the adolescents were having beliefs supporting aggression. According to WHO, up to $20 \%$ adolescents have one or more mental or behavioral problems. ${ }^{8}$

Aggression scale revealed that about $47.1 \%$ of study subjects used to tease other students to make them angry of which
$13.2 \%$ did it for more than four times in a week. Nearly two third of the study subjects (69.3\%) got angry easily with someone of which $13.5 \%$ subjects did it for more than six times a week. About $47.6 \%$ subjects fought back when hit first, of which $11.6 \%$ did it for more than six times a week which is quite high. Among study subjects, $58.9 \%$ used to tell things about other kids to make other students laugh. Most of them (76.5\%) had not encouraged other students to fight and nearly (73.4\%) of them not pushed/shoved other students. Nearly $47 \%$ of them got angry most of the day. About $74.6 \%$ students do not get into a physical fight in anger. About $29.5 \%$ of subjects slapped or kicked someone out of which $9 \%$ did it for more than 6 times a week. Nearly $38.7 \%$ participants called other students by bad names. Most (73.4\%) of the students have not threatened to hurt or to hit someone. This, suggests that most of the school going children scored higher on aggression scale. Aggression and violence are quite frequent in the Indian society, yet there is a severe lack of quantitative empirical data on childhood aggression. Studies on children before the onset of adolescence are important because this is a period for rapid mental and physical changes involved in shaping the adaptive behavior traits in response to environmental challenges and children are more likely to respond to behavioral. It is a potential outcome of psychosocio-cultural settings appears to be a very important aspect of personality. As aggressors always remain at high risk due to their risky life styles that may lead to development of behavioral problems, delinquency, substance or chemical dependence and other medical conditions such as cardiovascular problems, cancer and brain damage.

It was found that that out of the total participants $55.8 \%$ were males and $44.2 \%$ were females. It was found that males were having significantly more scores on aggression scale than females $(p=0.004)$. It shows males were more aggressive than females. It may be due to a strong relation of testosterone with aggression. ${ }^{9,10,11,12}$ Overall testosterone level of male is significantly higher than females. It is corroborative with the findings from a meta-analysis. ${ }^{13}$

Table 4 shows that total aggression score was higher among adolescents aged $12-13$ years, $14-15$ years as compared to those aged $16-17$ years and $18-19$ years. The present study shows that the aggression score was higher among younger adolescents which is contradictory with some other studies. ${ }^{14}$ However, the number of students in early adolescent group being small in the present sample and observed differences were statistically insignificant 
$(p=0.068)$. Decreasing trends in levels of aggressiveness in most children after about 5 years of age have been generally reported in previous studies. ${ }^{15}$ In another study carried out in Punjab it was found that aggression scores were more in younger adolescents as compared to older adolescents. ${ }^{16}$ Similar findings were found by Datta and Firdoush (2012) which states that specifically for physical aggression younger adolescents scored higher while other types of aggression were found to be higher among older age groups. ${ }^{17}$ Such trends were observed in our study where, mean score of aggression was higher in younger adolescent (14.2 \pm 13.4$)$ as compared to $18-19$ years $(5.28 \pm 4.2)$. Non-significant difference in present study could also be due to the type of school and region in which the school is located.

Majority belonged to nuclear families (54.5\%) and were Hindus (84.3\%). In the present study the family type and religion did not influence the aggression profile of adolescents. In regard to the educational status of the parents it was found that those adolescents whose parents were having higher degrees were having more aggression scores as compared to less educated parents. Though there was no statistically significant association with aggression scores. It was also revealed that adolescents whose mothers were working were found to be less aggressive than those whose mothers were homemakers. This difference was also not statistically significant. Similar finding was observed by Jain $\mathrm{K}$ et.al, where there was no significant difference of aggression scores among different religions and types of the families as well as working status of mothers. ${ }^{18}$ However, in another study, it was found that adolescents of working mothers had more aggression than non-working mothers but findings regarding father' working status didn't show any significance. ${ }^{16}$ Such difference is again could be due to difference in religion and region.

The present study had limitation in the form of survey design because data was collected by self-reporting questionnaires which has inherent weakness of getting true responses. Although the aggression scale was validated and widely used tool.

\section{Conclusion}

Aggression is prevalent among school adolescents and is higher among boys as compared to girls. Other sociodemographic factors didn't find association with aggression among adolescents and needs further research. However, there is an urgent need of effective preventive and management strategy for school health program.

\section{Conflict of Interest: None}

\section{References}

1. Krug EG, Dahlberg LL, Mercy JA, Zwi AB, Lozano R. World Report on Violence and Health. Geneva, Switzerland: WHO; 2002. Available From: https://apps.who.int/ iris/bitstream/handle/10665/42495/9241545615_ eng.pdf; jsessionid=248DBOD 7C76C7342AE21C1888AE24B25? sequence=1.

2. National Crime Research Bureau Report. India: Ministry of Home Affairs; 2013.

3. Ferguson CJ, Beaver KM. Natural born killers: The genetic origins of extreme violence. Aggression and Violent Behavior 2009; 14(5): 286-294. Available From: http://www.antoniocasella.eu/nume/Ferguson_2009. pdf [Google Scholar].

4. Bjorkqvist K, Lagerspetz KM, Osterman K. The Direct and Indirect Aggression scale (DIAS). Finland: Abo Akademi University, Department of Social Sciences. 1992. Available From: http://vinst.umdnj.edu/VAID/ Testdata. asp?Code=DIAS.

5. Center for Behavioral Health Statistics and Quality. The NSDUH Report: Violent Behaviors among Adolescent Females. Rockville, MD: Substance Abuse and Mental Health Services Administration. 2009.

6. American Psychiatric Association. Diagnostic and Statistical Manual of Mental Disorders (4th Ed.) 1994. Available From: https://psycnet.apa.org/ record/1994-97698-000.

7. Sharma MK, Marimuthu P. Prevalence and psychosocial factors of aggression among youth. Indian J Psychol Med 2014; 36(1): 48-53. Available From: http://www. ijpm.info/article. asp? issn=0253-7176; year $=2014$; vol ume $=36$; issue $=1 ;$ spage $=48$; epage $=53$; aulast $=$ Sharma [PubMed/ Google Scholar].

8. The World Health Report 2001. Mental health: New understanding, new hope. Geneva: World Health Organization 2001; 39-44.

9. Terburg D, Morgan B, van Honk J. The testosteronecortisol ratio: A hormonal marker for proneness to social aggression. Int J Law Psychiatry 2009; 32(4): 216-223. Available From: https://s3.amazonaws.com/academia. edu.documents/45756303/The_testosteronecortisol_ratio_A_hormon20160518-10626-13b8osi. pdf?response-content-disposition=inline $\% 3 B \% 20$ filename\%3DThe_testosterone_cortisol_ratio_A_ hormon.pdf\&X-Amz-Algorith $m=A W S 4-H M A C-$ SHA256\&X-Amz-Credential=AKIAIWOWYYGZ2Y53 UL3A\%2F20191125\%2Fus-east-1\%2Fs3\%2Faws4_ request $\& X-A m z-D a t e=20191125 T 071320 Z \& X-A m z-$ Expires $=3600 \& X-A m z-S i g n e d H e a d e r s=h o s t \& X-A m z-S i$ gnature $=89 \mathrm{ca} 1 \mathrm{cf} 7 \mathrm{c} 1 \mathrm{e} 345795 \mathrm{f} 4 \mathrm{e} 0 \mathrm{~d} 9 \mathrm{fe} 5 \mathrm{abb} 772 \mathrm{cde} 1$ 118ddf97c64c4b14a70dfe6a840e [PubMed/ Google Scholar].

10. Hermans EJ, Ramsey NF, Van Honk J. Exogenous testosterone enhances responsiveness to social threat in the neural circuitry of social aggression in humans. Biol Psychiatry 2008; 63(3): 263-270. Available From: https://s3.amazonaws.com/academia.edu. 
documents/45756304/Exogenous_testosterone_ enhances_responsi20160518-12111-frcv7c. pdf?response-content-disposition=inline $\% 3 B \% 20$ filename\%3DExogenous_Testosterone_Enhances Responsi.pdf\&X-Amz-Algorithm=AWS4-HMACSHA256\&X-Amz-Credential=AKIAIWOWYYGZ2Y53 UL3A\%2F20191125\%2Fus-east-1\%2Fs3\%2Faws4 request $\& X-A m z-D a t e=20191125 T 071555 Z \& X-A m z-$ Expires $=3600 \& X-A m z-S i g n e d H e a d e r s=h o s t \& X-A m z-S i$ gnature=7d093019a4686c2e47e930917eb146d0093a b6f172b62c3c0d5c98f21b39b8ac [PubMed/ Google Scholar].

11. Mehta PH, Beer J. Neural mechanisms of the testosterone aggression relation: the role of orbitofrontal cortex. J Cogn Neurosci 2010; 22(10): 23572368. Available From: https://www.mitpressjournals. org/doi/abs/10.1162/jocn.2009.21389?rfr_dat=cr pub\%3Dpubmed\&url_ver=Z39.88-2003\&rfr_ id=ori\%3Arid\%3Acrossref.org\&journalCode=jocn [PubMed/ Google Scholar/ ResearchGate].

12. Kreuz LE, Rose RM. Assessment of aggressive behavior and plasma testosterone in a young criminal population. Psychosom Med 1972; 34(4): 321-332. Available From: https://insights.ovid.com/psychosomatic-medicine/ psme/1972/07/000/assessment-aggressive-behaviorplasma-testosterone/6/00006842 [PubMed/ Google Scholar].

13. Card NA, Stucky BD, Sawalani GM, Little TD. Direct and Indirect aggression during childhood and adolescence: a meta-analytic review of gender differences, intercorrelations, and relations to maladjustment. Child Dev 2008;79(5): 1185-1229. Available From: https:// srcd.onlinelibrary.wiley.com/doi/abs/10.1111/j.14678624.2008.01184.x [PubMed/ Google Scholar]

14. Kumari S, Kishore J and Mandal RK. A cross-sectional study of Aggression among school adolescents in Karnatake. India Ind J Youth Adol Health 2017; 4(4): 4-9. Available From: http://iaah1992.org/upload/ researchandpublication/1547281446.pdf [DOI: https:// doi.org/10.24321/2349.2880.201728/ Google Scholar].

15. Tremblay RE, Nagin DS, Séguin JR, Zoccolillo M, Zelazo $\mathrm{PD}$, Boivin $\mathrm{M}$ et al. Physical aggression during early childhood: Trajectories and predictors. Pediatrics 2004;114: e43-50. [PubMed/ Google Scholar].

16. Garg I, Sethi S, Kishore J. The Prevalence and Patterns of Aggression in School Adolescents in a Rural Area of Moga District of Punjab, India. Ind J Youth Adol Health 2018; 5(1): 43-46. [DOI: https://doi. org/10.24321/2349.2880.201805/ Google Scholar].

17. Datta PP, Firdoush KA. Association of aggression with socio-demographic characteristics: a cross-sectional study among rural adolescents. Natl J Med Res 2012; 2(4): 442-447.
18. Jain K, Sharma S, Prajna SC, Jain V. Influences of Gender, Religion, Dietary Patterns, and Mixed-sex Education on Aggressiveness in Children: A Sociodemographic Study in Municipal Primary Schools of South Delhi. Indian J Public Health 2018; 62(1): 21-26. Available from: http://www.ijph.in/article.asp?issn=0019-557X; year $=2018$; volume $=62$; issue $=1$; ppage $=21$; epage $=26$; a ulast=Jain [PubMed/ Google Scholar]. 